\title{
Potential Tree Species as a Source of Air Filters to Capture Particulate Matter of the Atmosphere
}

\author{
P.A.P.M. Pallawala, S.A.E.C. Wijesinghe* and K. Yakandawala
}

\begin{abstract}
Particulate pollution has become a serious health and environmental issue in Sri Lanka. Road side trees planted primarily for aesthetic purposes, provide coolness and shade, improve micro climate and reduce dust particles in air. However, there is little information on tree species for intercepting dust particles. Thus, the objective of this study was to identify potential tree species that could be used to reduce dust particles in urban areas. Six commonly used roadside tree species, Terminalia arjuna, Azadirachta indica, Tamarindus indica, Khaya senegalensis, Thevetia peruviana and Senna surattensis were selected for the study. Both quantitative and qualitative morphological characters which contribute effectively to mitigate dust particles were studied in all species. Based on the characters which contribute to a coarse texture and dense canopy, $T$. arjuna and $S$. surattensis can be recommended over other species for road side planting to reduce air pollution caused by dust particles and also to obtain aesthetic benefits in landscaping.
\end{abstract}

Keywords: Air pollution, Dust particles, Morphological characters, Road side trees

\section{INTRODUCTION}

There is a significant air pollution in Sri Lanka with increasing economic prosperity and increasing population. Air pollution can be defined as any solid, liquid or gaseous substances present in the atmosphere in such concentrations that may tend to be injurious to human beings or other living creatures or plants or property or enjoyment (Purohit and Agrawal, 2006).

Department of Horticulture and Landscape Gardening, Faculty of Agriculture and Plantation Management, Wayamba University of Sri Lanka, Makandura, Gonawila (NWP), 60170, Sri Lanka *wijesingheerandi@yahoo.com
Industrialization, urbanization, lack of awareness, increasing number of motor vehicles and badly maintained roads can be considered as the major causes of air pollution (Joshi and Chauhan, 2008). In Sri Lanka, Colombo Metropolitan Region was identified as an area with high air pollution followed by Kandy town area, Galle, Kurunagala and Puttalam (Anon, 2011). Vehicle emission has been found to be a significant source of particulate contaminations (Matsumoto and Tanaka, 1996).

Particulate matter (PM) is minute (10 $\mu \mathrm{m}$ and smaller) solid particles and liquid particles dispersed in the atmosphere. It includes dust, ash, soot, lint, pollen, spores, algal cells and many other suspended materials (Enger and Smith, 2004). According to the aerodynamic diameter, $\mathrm{PM}$ can be divided into fine $\left(\mathrm{PM}_{2.5}\right.$ $/<2.5 \mu \mathrm{m})$ and coarse particles $\left(\mathrm{PM}_{10}\right.$ $<10 \mu \mathrm{m})$.

Pollution caused by particulates is a serious health problem throughout the world, exacerbating a wide range of respiratory and vascular illnesses in urban areas (Beckett et al., 2000). The fine particles are capable of penetrating through the lungs and accumulating in blood stream and are therefore important regarding human (Dominici et al., 2006). Diseases of the respiratory system ranked as the second leading cause of hospitalization in Sri Lanka (Senerath, 2003). Dockery et al., (1989) reported positive associations between rates of chronic coughs, bronchitis and chest illness in school children and particulate pollution in the United States of America. A close relationship was revealed 
between air pollution in Colombo and acute childhood wheezing (Senanayake et al., 1999).This is a serious matter especially among school children as most of the city schools are situated along busy roads (Anon, 2012).

The abatement measures to reduce sources of particulate matter are generally costly, while natural sources are difficult or impossible to control. It is therefore becomes vital to explore alternatives to lower particle concentration in urban areas. The use of vegetation in filtering out particulates from the atmosphere has long been accepted and is common practice in some developed countries (Kulshreshtha et al., 2008). For an example, in USA, urban trees and shrubs remove 215 kilotons of $\mathrm{PM}_{10}$ a year (Nowak, 2006). Trees along roadsides establish primarily for aesthetic purposes, obtaining shade and coolness, attenuate noise, improve the micro-climate and effectively reduce particulate pollution (Varshney and Mithra, 1993). Removal of air pollutants by plants from air is by three means, absorption, deposition and fallout from the leeward side of the vegetation (Prajapathi and Tripathi, 2008). Deposition of dust depends on the physical characteristics of particles and also the plant species (Harrison and Yin, 2000).

In Sri Lanka few studies were conducted to find out the relationship between the morphological characters and dust trapping efficiency of shrubs (Wijesinghe and Yakandawala, 2009; Kodikara and Yakandawala, 2010; Jayasinghe and Yakandawala, 2011). However, information on potential trees which can intercept dust particles efficiently is not available in Sri Lanka. Therefore, this study was conducted with the objective of identifying potential tree species with desirable morphological features that are capable of contributing positively for intercepting dust particles along roadsides.

\section{MATERIALS AND METHODS}

\section{Location}

The study was conducted at the Faculty of Agriculture and Plantation Management, Wayamba University of Sri Lanka, Makandura, in early 2013.

\section{Collection of Materials}

Six commonly found roadside tree species, namely Terminalia arjuna (Roxb.) Wight and Arn. ("Kumbuk"), Azadirachta indica A. Juss. ("Kohomba"), Tamarindus indica L. ("Siyambala"), Khaya senegalensis (Desr.) A. Juss ("Khaya"), Thevetia peruviana juss ("Kaneru") and Senna surattensis (Burm.f.) H.S.Irwin \& Barneby were selected for the study (Plate 1). The samples were collected along Wariyapola Kurunegala main road between Wariyapola and Werapola. Five individual trees were selected randomly to represent a tree species and two mature twigs were selected from each individual. Then from each tree species, ten mature twigs were collected to measure quantitative and qualitative morphological characters as described by Wijesinghe and Yakandawala (2009).

\section{Quantitative Morphological Characters of Leaves and Barks}

From each selected twig, petiole length and inter-nodal distance were measured by visual observations. Three mature leaves were used from each twig to measure leaf width and length (visual observations). An eye piece graticule was used to measure hair length under the light microscope and hair density was measured using compound microscope (Table 1). 


\section{Qualitative Morphological Characters of Leaves}

The qualitative characters were recorded as described by Hickey and King (2000). Leaf arrangement, margin, orientation, folding and prominent venation of leaves were visually observed. Hairs on petiole, stem, leaf margin, hair type and cell arrangement of hairs were studied under the compound microscope. Texture of bark surface and branching habit of selected species were visually identified (Table 2).

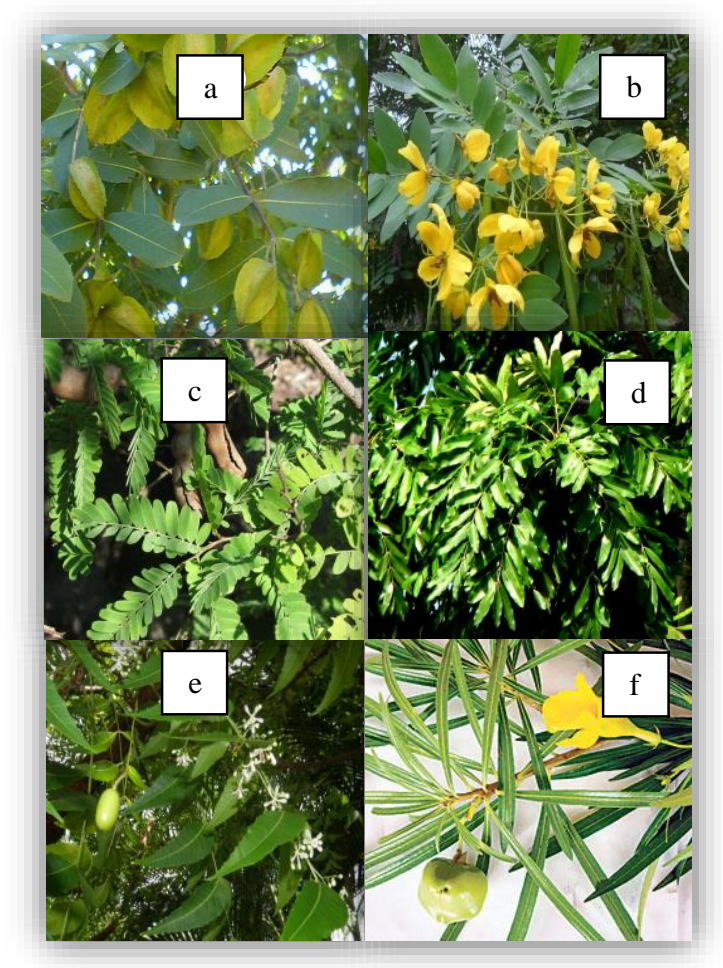

Plate 1: Plant species selected for the study: a) Terminalia arjuna, b) Senna surattensis c) Tamarindus indica, d) Khaya senegalensis, e) Azadirachta indica, f) Thevetia peruviana

\section{Data Analysis}

Data were subjected to ANOVA procedure of Statistical Analysis System (SAS). Mean comparison was performed using Least Significant Difference (LSD) test to examine whether the difference among variables were significant at 5\% probability level.

\section{RESULTS}

\section{Quantitative Morphological Characters of Leaves}

The internodal distance varied from $1.86 \mathrm{~cm}$ to $5.59 \mathrm{~cm}$. Significantly shorter internodal distance was recorded in $T$. peruviana followed by $K$. senegalensis, $T$. arjuna and $A$. indica. When consider the petiole length, it varied from $0.37 \mathrm{~cm}$ to $13.52 \mathrm{~cm}$. Significantly shorter petiole lengths were recorded in $T$. peruviana, $T$. arjuna and $T$. indica. The longest petiole length was recorded in $K$. senegalensis.

Leaf length varied from $8.54 \mathrm{~cm}$ to $29.11 \mathrm{~cm}$. Khaya senegalensis recorded a significantly higher leaf length followed by S. surattensis, A. indica and T. arjuna. Leaf width varied from $1.04 \mathrm{~cm}$ to $22.66 \mathrm{~cm}$ while $K$. senegalensis recorded significantly higher leaf width followed by A. indica, S. surattensis and T. arjuna. Leaf hairs were present on upper surface only in T. arjuna and $A$. indica while on lower surface in $T$. arjuna, $A$. indica and $S$. surattensis. In $T$. arjuna hair density was significantly high compared to other species. Length of leaf hairs varied from $0.70 \mathrm{~mm}$ to $0.95 \mathrm{~mm}$ and $S$. surattensis recorded significantly longer leaf hairs.

\section{Qualitative Morphological Characters of Leaves}

Spiral leaf arrangement was observed in T. peruviana, S. surattensis, A. indica and $K$. senegalensis. Tamarindus indica possesses alternate leaf arrangement while $T$. arjuna possesses opposite leaf arrangement (Plate 2). All species possess semi erect leaf orientation except $K$. senegalensis and T. peruviana. All species possess carinate leaf folding. Prominent venation was recorded in all species except 
in T. indica and T. peruviana. Out of species studied, T. arjuna, S. surattensis and $A$. indica possess hairs in their leaves.

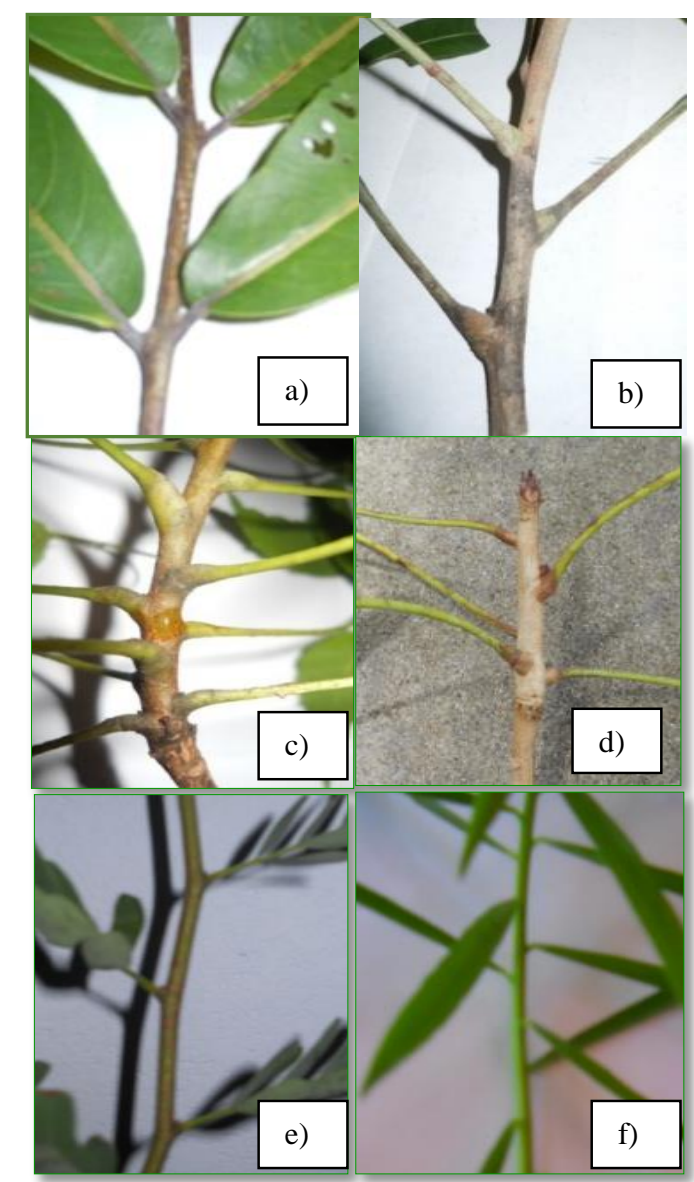

Plate 2. Leaf arrangement of selected species: a)Terminalia arjuna, b)Senna surattensis c) Khaya senegalensis, d) Azadirachta indica, e) Tamarindus indica, f)Thevetia peruviana

When consider the hair types of the species, $A$. indica, T. arjuna (Plate 3 and 4) and S. surattensis (Plate 5 and 6) possess unicellular solitary hairs. However, $T$. arjuna, $T$. indica and $S$. surattensis showed hairs on stem, petiole and leaf margin. $T$. indica possesses hairs only on one side of the leaf margin. S. surattensis possesses hairs only on lower leaf surface while $A$. indica recorded hairs on midrib. Tamarindus indica, S. surattensis, $T$. peruviana and $K$. senegalensis possess entire leaf margin while $A$. indica recorded serrate leaf margin. Terminalia arjuna showed crenate leaf margin (Plate 7).

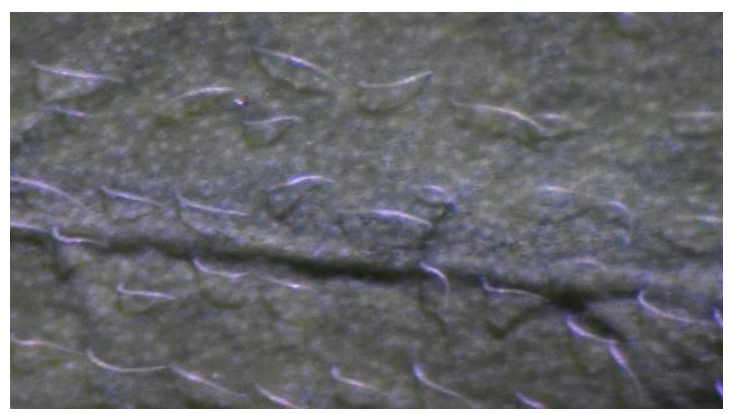

Plate 3. Microscopic view of lower leaf surface of T. arjuna $(4 \times 4)$

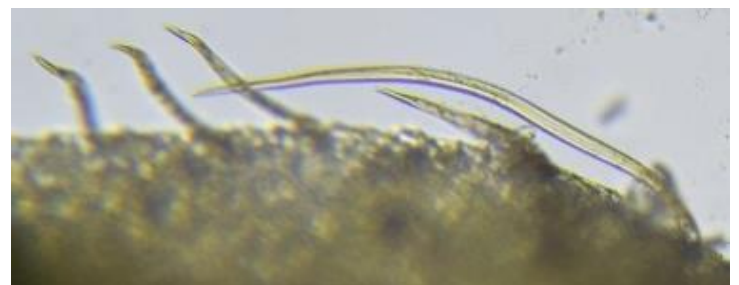

Plate 4. Microscopic view of lower leaf surface of $T$. arjuna $(4 \times 40)$



Plate 5. Microscopic view of lower leaf surface of $S$. surattensis $(4 \times 4)$

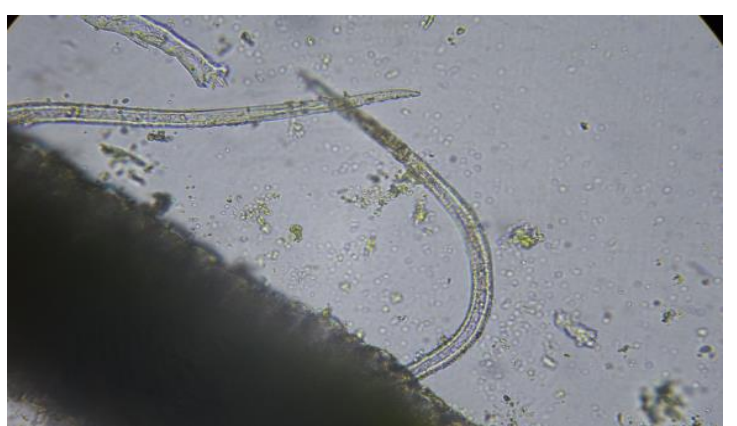

Plate 6. Microscopic view of lower leaf surface of $S$. surattensis $(4 \times 40)$ 


\section{DISCUSSION}

Ability of a plant to intercept particles depends on its external microscopic and macroscopic morphological features which include internodal distance, petiole length, leaf folding, shape of leaf margin, hair type, hair length, hair density, leaf venation, leaf arrangement, leaf orientation, hairs on stem and petiole (Yunus et al., 1985; Prajapathi and Tripathi, 2008; Wijesinghe and Yakandawala, 2009; Kodikara and Yakandawala, 2010; Jayasinghe and Yakandawala, 2011). Most of these morphological features collectively contribute to dense canopy and coarse texture of leaves that are very important factors for mitigating dust particles in air. According to Prajapathi and Tripathi (2008) shorter internodal distance, shorter petiole and high surface area have direct contribution to particle interception. When considering dust retention ability, petiole
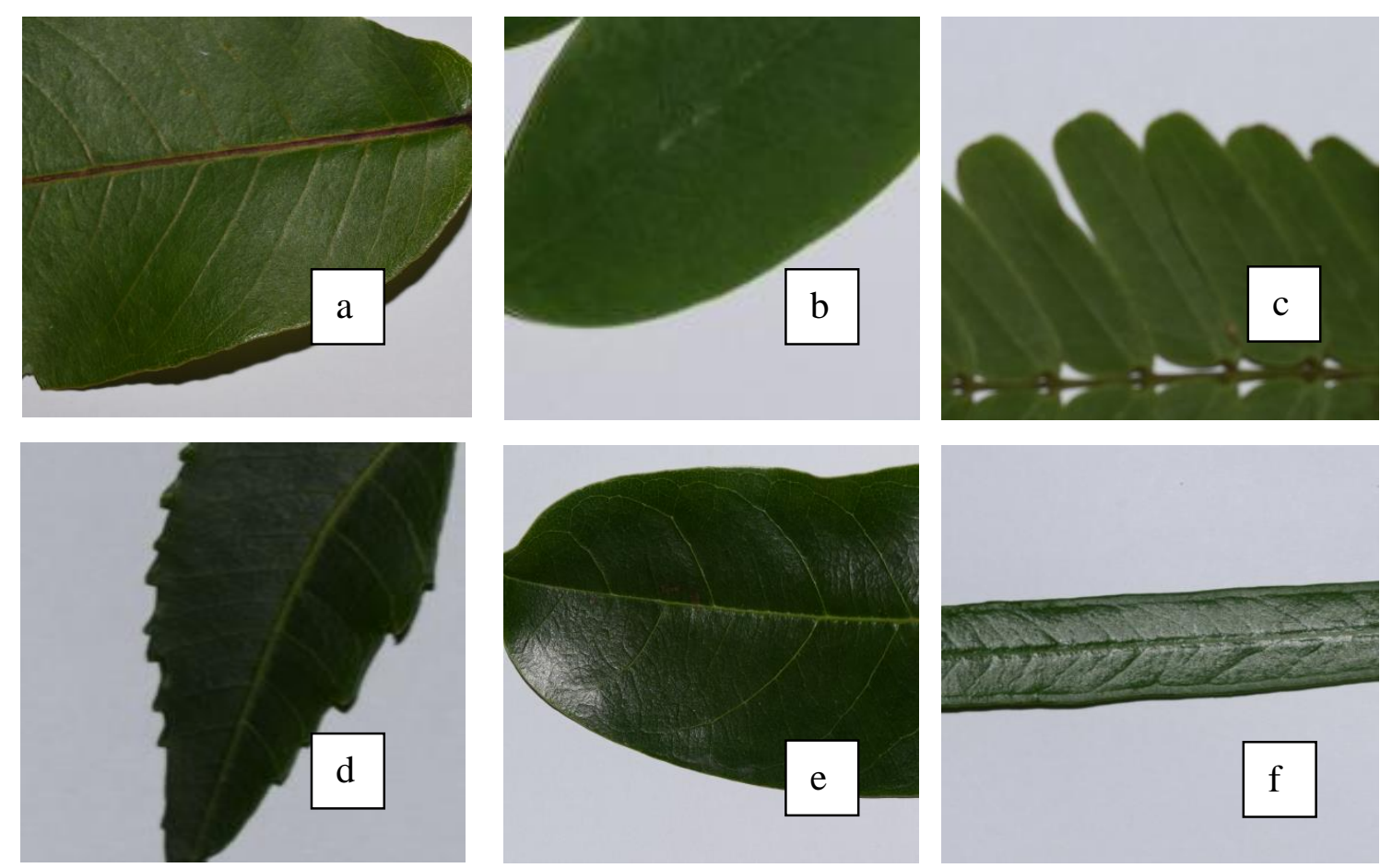

Small petioles reduce movement of leaves in wind thus, it increases dust accumulation in the leaves (Prajapathi and Tripathi, 2008). When considering the leaf arrangements apart from opposite, all other leaf arrangement types minimize the space in between and therefore give a complete cover. Further, leaf margins apart from entire, contributes to increase surface area that give positive contribution to dust accumulation. Considering the leaf orientation either horizontal or semi erect position reduces the inter-space among the adjacent leaves contributing to a dense cover. All these features help to increase the canopy density of a plant species.

Plate 7. Leaf margins of selected plant species: a) T. arjuna b) S. surattensis c) T. indica d) A. indica e) $K$. senegalensis f)T. peruviana 
Table 1. Quantitative morphological characters examined during the study

\begin{tabular}{|c|c|c|c|c|c|c|c|}
\hline \multicolumn{8}{|c|}{ Morphological character } \\
\hline $\begin{array}{l}\text { Tree } \\
\text { speci } \\
\text { es }\end{array}$ & $\begin{array}{l}\text { Internodal } \\
\text { Distance } \\
(\mathrm{cm})\end{array}$ & $\begin{array}{l}\text { Petiole } \\
\text { length } \\
(\mathrm{cm})\end{array}$ & $\begin{array}{l}\text { Leaf } \\
\text { length } \\
(\mathrm{cm})\end{array}$ & $\begin{array}{l}\text { Leaf } \\
\text { width } \\
(\mathrm{cm})\end{array}$ & $\begin{array}{l}\text { Leaf upper } \\
\text { surface hair } \\
\text { density }\end{array}$ & $\begin{array}{l}\text { Leaf } \\
\text { lower } \\
\text { surface } \\
\text { hair } \\
\text { density }\end{array}$ & $\begin{array}{l}\text { Average } \\
\text { hair } \\
\text { length } \\
(\mathrm{mm})\end{array}$ \\
\hline SS & $5.59^{\mathrm{a}}$ & $7.17^{b}$ & $19.33^{b}$ & $13.25^{\mathrm{c}}$ & - & $4.87^{\mathrm{b}}$ & $0.95^{\mathrm{a}}$ \\
\hline TA & $4.50^{\mathrm{bc}}$ & $0.77^{\mathrm{c}}$ & $15.68^{\mathrm{c}}$ & $5.75^{d}$ & $5.37^{\mathrm{a}}$ & $20.17^{a}$ & $0.70^{\mathrm{b}}$ \\
\hline $\mathrm{TI}$ & $4.77^{\mathrm{b}}$ & $1.00^{\mathrm{C}}$ & $8.54^{\mathrm{e}}$ & $3.23^{\mathrm{e}}$ & - & - & - \\
\hline $\mathrm{AI}$ & $4.49^{\mathrm{bc}}$ & $6.33^{b}$ & $17.87^{\mathrm{bc}}$ & $14.70^{\mathrm{b}}$ & $2.43^{b}$ & $3.00^{c}$ & $0.72^{b}$ \\
\hline TP & $1.86^{\mathrm{d}}$ & $0.37^{\mathrm{c}}$ & $12.42^{\mathrm{d}}$ & $1.04^{\mathrm{f}}$ & - & - & - \\
\hline \multirow[t]{2}{*}{ KS } & $3.90^{c}$ & & $29.11^{\mathrm{a}}$ & $22.66^{\mathrm{a}}$ & - & - & - \\
\hline & & $13.52^{\mathrm{a}}$ & & & & & \\
\hline
\end{tabular}

Means in a column with the same letters are not significantly different at $p<0.05$ level. S. surattensis - (SS), Terminalia arjuna - (TA), Tamarindus indica - (TI), Azadirecta indica - (AI), Thevetia peruviana- (TP), Kahaya senegalensis-(KS)

Table 2. Qualitative morphological characters examined during the study

\begin{tabular}{|c|c|c|c|c|c|c|c|c|}
\hline \multirow[t]{2}{*}{ Leaf character } & \multicolumn{8}{|c|}{ Tree species } \\
\hline & SS & TA & & TI & $\overline{\mathrm{AI}}$ & & $\mathrm{TP}$ & $\mathrm{KS}$ \\
\hline Arrangement & S & $\mathrm{O}$ & & A & S & & S & S \\
\hline Margin & E & $\mathrm{C}$ & & $\mathrm{E}$ & S & & $\mathrm{E}$ & $\mathrm{E}$ \\
\hline Orientation & SE & SE & & SE & SE & & $\mathrm{E}$ & $\mathrm{H}$ \\
\hline Folding & $\mathrm{C}$ & $\mathrm{C}$ & & $\mathrm{C}$ & $\mathrm{C}$ & & $\mathrm{C}$ & $\mathrm{C}$ \\
\hline $\begin{array}{l}\text { Prominent } \\
\text { venation }\end{array}$ & + & & + & - & + & & - & + \\
\hline Leaf hair type & $S$ & S & & - & $\mathrm{S}$ & & - & - \\
\hline $\begin{array}{l}\text { Hairs cell } \\
\text { arrangement }\end{array}$ & Uni & & Uni & - & & Uni & - & - \\
\hline $\begin{array}{l}\text { Hairs on } \\
\text { petiole }\end{array}$ & + & & + & + & - & & - & - \\
\hline Hairs on stem & + & + & & + & - & & - & - \\
\hline $\begin{array}{l}\text { Hairs on leaf } \\
\text { margin }\end{array}$ & + & + & & + & - & & - & - \\
\hline
\end{tabular}

Leaf arrangement : Alternate $-A$, Opposite $-O$, Spiral $-S$; Margin : Crenate $-C$, Entire $-E$; Orientation: Semi erect - SE, Horizontal- H; Folding: Carinate - C, Flat- F ; Prominent venation : present +, Absent -; Leaf hair type: Cluster- C, Solitary - S; Hairs cell arrangement: Unicellular- Uni; Hairs on petiole: present +, Absent - ; Hairs on stem: present +, Absent - ; Hairs on leaf margin: present +, Absent - 
Apart from density of the canopy, coarse texture of the leaf lamina is effective in trapping particles in air (Ingold, 1971). Presence of hair and prominent veins on leaves positively contribute to the texture of leaves. The density, length and type of hairs influence over the coarse texture and there by on particulate interception ability. These microscopic structures can increase the effective surface area of leaves and trap particulates among them (Yunus et al., 1985).

Terminalia arjuna and S. surattensis have a significant potential to intercept particles in air compared to other species because they possess desirable morphological features which contribute to the density of their canopy and coarse texture of leaves. Terminalia arjuna has shorter petiole length and semi erect leaf orientation that contribute towards a dense canopy while crenate leaf margin increases the effective surface area available to trap particles. Whereas the presence of hairs on both leaf surfaces, longer hairs and prominent venation contribute towards a coarse leaf texture. Further, hairs can be observed in petioles, stem and leaf margin which increase efficiency of particle interception ability. In S. surattensis, spiral leaf arrangement, semi erect leaf orientation and carinate leaf folding contribute towards a dense canopy. The presence of hairs on leaf lower surface, particularly longer hairs and prominent venation contribute towards a coarse leaf texture.

Though Azadirecta indica has high leaf length and width with coarse leaf texture it does not possesses a dense canopy due to its significantly long petioles and inter-nodes. Though $K$. senegalensis has high leaf length and width it does not produce dense canopy due to its significantly long petioles, internodes and horizontal leaf orientation. In addition, it possesses smooth textured leaves due to the absence of leaf hairs.
Thevetia peruviana has shorter internodal distance and petiole length compared to other species. However, leaf width and length were significantly low. In addition, hairs were absent on both surfaces of the leaves. Therefore, particle interception ability is low. In T. indica, erect leaf orientation, low leaf length and width and long internodes contribute towards sparsely canopy though it has shorter petioles. Further, it has no hairs on leaf lower and upper surfaces.

Based on the present study, T. arjuna and $S$. surattensis can be recommended as potential tree species to intercept dust particles along roadsides. In addition, $S$. surattensis has attractive yellow colour flowers and T. arjuna has brownish pink colour bark that are aesthetically valuable in landscaping.

\section{CONCLUSION}

Out of six roadside species studied, $T$. arjuna and $S$. surattensis have dense canopy and coarse textured leaves which contribute positively for capturing dust particles from air. Therefore, T. arjuna and S. surattensis can be recommended to plant along road sides to obtain health benefits together with functional benefits and aesthetic aspects.

\section{ACKNOWLEDGEMENT}

The authors wish to express their gratitude to Mr. K.M.M.I. Karunarathne for statistical analysis and to Mr. C.N Fernando for technical assistance.

\section{REFERENCES}

Anon, (2011). Available from:
https://www.
environmentmin.gov.lk/web/pdf/englis
h_annual_report.pdf (Accessed 22
March 2013).


Anon, (2012). Available from: https://www.

ccpsl.lk/wpcontent/files_mf/oration_s umalnandasena.pdf (Accessed 26 March 2013).

Beckett, K.P., Freer-Smith, P.H. and Taylor, G. (2000). Particulate pollution capture by urban trees: effect of species and wind speed. Global change Biology. 6, 995-1003.

Dockery, D.W., Speicer, F.E., Strram, D.O., Ware, J. H., Spengler, J.D. and Ferris, B. G. (1989). Effects of inhalable particles on respiratory health of children. American. Review of Respiratory Diseases, 139 (3), 587594.

Dominici, F., Peng R. D. and Bell, M. L. (2006). Fine particulate air pollution and hospital admission for cardiovascular and respiratory diseases. The Journal of the American Medical Association, 295, 1127-1134.

Enger, E.D. and Smith, B.F. (2004). Air Quality Issues. Environmental Science. 17 (9), 390-391.

Harrison, R.M. and Yin, J. (2000). Particulate matter in the atmosphere: Which particle properties are important for its effect on health?. Science Technology Environment. 249, 85-101.

Hickey, M. and King, C. (2000). The Cambridge Illustrated Glossary of Botanical Terms. Cambridge, University press, Cambridge.

Ingold, C.T. (1971). Fungal spores. Clarendon Press, Oxford.

Jayasinghe, K.W.A.C.R. and Yakandawala, K. (2011). Impact of urban landscape plants in mitigating air pollution. In proceeding of the $11^{\text {th }}$ Agricultural Research Symposium, 20-21 September, 2011. Wayamba University of Sri Lanka. 91-95.
Joshi, P.C. and Chauhan, A. (2008). Performance of locally grown rice plants (Oryza sativa L.) exposed to air pollutants in a rapidly growing industrial area of district Haridwar, Uttarakhand, India. Life Science Journal, 5 (3), 41-45.

Kodikara, K.A.L.R. and Yakandawala, K. (2010). Dust interception ability of some selected shrubs used as hedges in landscaping. In proceeding of the $10^{\text {th }}$ Agricultural Research Symposium, 13-14 August, 2009. Wayamba University of Sri Lanka. 89-92.

Kulshreshtha, K., Rai, A., Mohamantye, C.S., Roy, R.K. and Sharma, S.C. (2008). Particulate pollution mitigating ability of some plant species, 3 (1), 137-142.

Matsumoto, K. and Tanaka, H. (1996). Formation and dissociation of atmospheric particulate nitrate and chloride: an approach based on phase equilibrium.

Atmospheric Environment, 30, 639-648.

Nowak, D.J., Crane, D.E. and Stevens, J.C. (2006). Air pollution removal by urban trees and shrubs in the United States. Urban Forestry and Urban Greening 4: 115-123.

Prajapathi, S.K. and Tripathi, B.D. (2008). Seasonal variation of leaf dust accumulation and pigment content in plant species exposed to urban particulates pollution. Journal of Environmental Quality, 37, 870-885.

Purohit, S.S. and Agrawal, K. (2006). Environmental Pollution. Agrobios press, India.

Senanayake, M.P., Samarakkody, R.P., Jayasinghe, S.R., Prasad, K.A.L., Hettiarachchi, A.P., Sumanasena, S.P. and Kudalugodaarachchi, J. (1999). Association between ambient air pollution and acute childhood wheezy episodes in Colombo. In proceeding of 
Forestry Symposium, 1999. University of Sri Jayawardanapura, Gangodawila, Nugegoda.

Senerath, C. (2003). An overview of air pollution and respiratory illnesses in Sri Lanka. In proceeding of $3^{\text {rd }}$ International Conference on Environment and Health.15-17 December, 2003. Chennai, Madras University of India, 489-501.

Varshney, C.K. and Mithra, L. (1993). Importance of hedges in improving urban air quality. Landscape and Urban Planning. 25, 75-83.

Wijesinghe, S.A.E.C. and Yakandawala, K. (2009). Particulate matter interception ability of some selected shrubs used in urban landscaping. In proceeding of the $9^{\text {th }}$ Agricultural Research Symposium, 13-14 August, 2009. Wayamba University of Sri Lanka. 363-367.

Yunus, M., Dwivedi, A.K., Kulshreshtha, K. and Ahmad, K.J. (1985). Dust loadings some common plants near Lucknow city. Environment Pollution. 9, 71-80. 